\title{
Honey Bee Colony Absconding and Associated Risk Factors Facing Beekeepers in Bure Zuria Woreda, North Western Ethiopia
}

\author{
Yaregal Shiferaw \\ Department of Biology, College of Natural and Computational Sciences, \\ Wollega University, Nekemte, Ethiopia \\ Oljira Kenea* \\ Department of Biology, College of Natural and Computational Sciences, \\ Wollega University, P.O. BOX 395, Nekemte, Ethiopia
}

\begin{abstract}
In Ethiopia, beekeeping is based on traditional hives which accounts for more than $95.5 \%$ of the hive types while transitional and frame beehives are about $4.3 \%$ and $0.2 \%$ respectively. The aim of this study was to assess honeybee colony absconding from traditional hives and associated risk factors in Bure Zuria Woreda, north western Ethiopia. A total of 50 beekeepers were selected randomly for a longitudinal apiary inspection survey to determine honey bee colonies owned by the beekeepers and pattern of honey bee colony absconding. However, a questionnaire was prepared and administered to all the beekeepers to assess the risk factors. Pearson chi-square $(\chi 2)$ was used to test association of risk factors for beekeeping at $\mathrm{p}$-value $<0.05$. Results showed that the overall number of honeybee colony positive hives owned by the beekeepers in the Kebele was $52(81.3 \%)$ whereas the overall colony negative hives was $12(18.7 \%)$. The number of bee colony absconding hives rose in February (17.2\%) and peaked in April (23.4\%) with sharp decline thereafter. Whereas the number of colony owning hives rose in October and peaked in December $(96.81 \%)$ than the rest of the inspection months. Pesticide and herbicide application, inadequate skill of beekeepers and deforestation were reported as the top risk factors associated with bee colony absconding in the study area. Therefore intervention to change traditional beekeeping practices through training and introducing improved beekeeping technologies that are suitable for local beekeepers are needed for mitigation of colony absconding and enhancing apiculture productivity and production in the study area.
\end{abstract}

Keywords: Beekeeper, Colony absconding, traditional hives, Wehni Durbete Kebele.

DOI: $10.7176 / \mathrm{JBAH} / 10-22-02$

Publication date: November $30^{\text {th }} 2020$

\section{Introduction}

Beekeeping is a long time agricultural practices in Ethiopia. It is an important component of agriculture and rural development program in the country. Beekeeping in the country is based on traditional hives. Generally, about 4,601,806 beehives exist in Ethiopia, out of which about $95.5 \%$ are traditional, $4.3 \%$ transitional, and $0.2 \%$ frame beehives (Beyene and David, 2007). The country owns the greatest bee density in Africa (Kassaye, 2001; Adgaba, 2002) and is the leading country in the content in honey and bees wax production and exporting (Adgaba, 2002).

However, the level of beekeeping and bee biodiversity conservation still remains in traditional system (Ejigu et al., 2009). Honey bee biodiversity conservation and beekeeping practices have been threatened by several biotic and abiotic environmental factors (Abebe and Jatema, 2015). As a result the number of honeybee colonies in the country has been decreasing from time to time due to various reasons such as population pressure, vegetation loss and inappropriate usage of agro-chemicals which facilitates bee colony decline and absconding (Belie, 2009; Tesfaye, 2015).

Absconding is the total loss of bee colonies from their hives due to various reasons. It differs from swarming in that the nest colony does not divide into two or more parts but the whole colony migrates to find a new nest site due to various problems. Bee species are subject to many diseases and pests like any other livestock and are exposed to absconding due to plenty of challenges. Absconding results in a loss in honey and wax formation due to a variety of negative issue such as shortage of bee equipment, shortage of pollen and nectar, deforestation, scarcity of water, rain, fire and spray of agro-chemicals (Bees for Development, 2000). The major absconding problems of honey bee colony (Apis mellifera) in many countries are not well-known and researched adequately (FAO, 2009). Likewise information on Ethiopian honey bee Apis mellifera colony absconding is lacking. Therefore, the aim of this study was to assess honey bee colony absconding and associated risk factors facing traditional beekeepers in Bure Zuria Woreda, north-western Ethiopia. The findings of the study are useful to the beekeepers to get basic information about their honey bee colonies absconding seasons and constraints for effective management of honey production by bee farmers. It provides further information about the underlying risk factors facing beekeepers that must be addressed to improve beekeeping and bee biodiversity conservation in the study 
setting.

\subsection{Materials and Methods}

\subsubsection{The Study Area}

Bure Zuria Woreda (BZW) is found in West Gojjam Zone of Amhara Region State in Ethiopia (Figure 1). It is located at $149 \mathrm{~km}$ from Bahirdar, the capital of the regional state and at $411 \mathrm{~km}$ from Addis Ababa. In Western Gojjam Zone there are 19 Woredas. It is geographically located at $10^{\circ} 17^{\prime} \mathrm{N}$ latitude and $37^{\circ} 00^{\prime} \mathrm{E}$ longitude. It has 24 kebeles (the lowest administrative unit)'. From the 24 Kebeles of BZW one Kebele particularly Wehni Durbete Kebele (WDK) was selected for this study based on accessibility and availability of beekeepers and honey production status. The kebele had a total of 6969 populations among these 3447 were males and 3522 females during the study period in 2019.

The area gets an average annual rainfall ranging from about $1000-1500 \mathrm{~mm}$. This is the main source of water for rain fed agriculture. The minimum and maximum daily temperature of the area was $17^{\circ} \mathrm{C}$ and $27^{\circ} \mathrm{C}$ respectively. The district has three economic-climate regions namely Lowland (Kola), Midland (Wyina Dega) and Highland (Dega) that make up about $21.77 \%, 77.23 \%$ and 1.0\% respectively. Mixed crop and livestock farming system is the mode of agricultural practice in the area. Hence peasants in the study area hold livestock species such as cattle, equines (horses, asses and mules), poultry and bee colonies and others which serve the household as source of meat, milk, honey and beeswax, income and means of transportation. Bee conservation is an integral part of the animal husbandry in the study area.

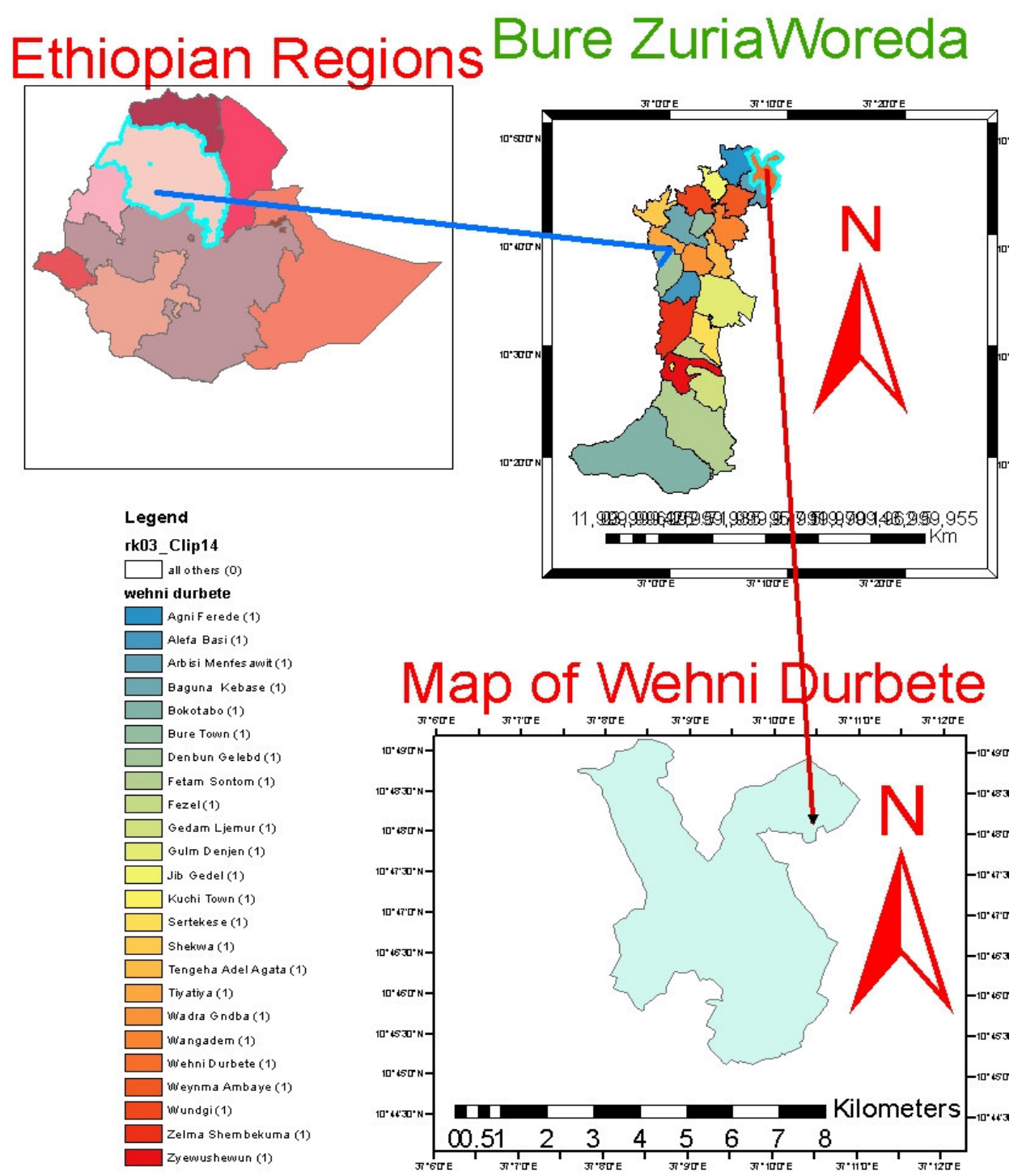

Figure 1: Map of Wehni Durbete Kebele in Bure Zuria Woreda, Western Ethiopia 


\subsubsection{Research Design}

A longitudinal apiary survey that involved both quantitative and qualitative data collections were undertaken from September 2018 up to May 2019 to gather basic information about honey bee colony absconding patterns and associated risk factors facing beekeepers in the selected Kebele and beekeepers' apiaries.

\subsubsection{Sampling Design and Determination of Sample Size}

To determine the pattern of colony absconding and colony density over honey cropping seasons, from a total of 18 Sub Kebeles in the WDK, five Sub-Kebeles were purposely selected based on accessibility and honey production. Sub Kebele refers to a small village in the administrative structure of the Ethiopian state that consists of a more closely related 35-40 household heads. From the five sub-kebeles, 10 beekeepers were randomly selected. A total of $50(10 \times 5)$ beekeepers were selected randomly to determine the number of honey bee colony positive hives owned by the beekeepers during the study period and the patterns of colony absconding. Simple observation was used to determine the number of honey bee colony positive hives owned by the beekeepers and to get information about the pattern of honey bee colony absconding over honey cropping seasons in a year. Observation protocols were prepared and used during field apiary inspection survey.

However, to assess risk factors facing beekeepers for honey production in the study area all the available traditional beekeepers in the Kebele were targeted and questionnaire were prepared and administered to all the beekeepers. The questionnaires prepared in both Amharic and English. The questionnaires were contained both open ended and close ended items.

In addition to the above respondents, eight key informants including two senior beekeepers, two agricultural officer, two Kebele officers, two Development Agents (DAs) were selected purposely for focused group discussion (FGD). In addition to questionnaires', the researcher also prepared a discussion points to discuss with the eight focused group members to gather further information which was not including in questionnaires'. The FGD was open ended. It was done in local language, Amharic.

The specific sample collection activities were taken place consecutively for three seasons (spring, winter and autumn) for 9 months from September 2018 to May 30/2019 fortnightly per month. Honey bee colony absconding inspection survey was undertaken fortnightly in apiary of the selected beekeepers. According to the Kebele agricultural office profile records WDK had a total of 167 male traditional and modern beekeepers. From these, 150 were traditional beekeepers and 17 were both traditional and modern beekeepers. Among 18 Sub Kebeles 5 sub-kebeles were selected randomly namely Tarenibora, Fendika, Mehalwehni, Adikuta and Terfamiba.

\subsubsection{Data Analysis Technique}

Statistical Package for Social Sciences (SPSS) version 20 was used for the analysis of quantitative data. Both qualitative and quantitative results were interpreted by descriptive statistics. The analyzed data were summarized in the form of table and graphs. The data obtained through focus group discussion were analyzed through qualitative techniques. Pearson chi-square $\left(\chi^{2}\right)$ was used to test association of risk factors for beekeeping at $p$ value $<0.05$

\subsection{Results}

\subsubsection{Traditional Apiaries Owned by the Beekeepers}

Typical traditional apiaries owned by the beekeepers were shown in Plates 1,2 and 3 respectively. The traditional beekeepers put their hives on the beds of wood, by hanging under thatched - roofed hut and corrugated sheet around homestead and also on trees near their home or far from their home.
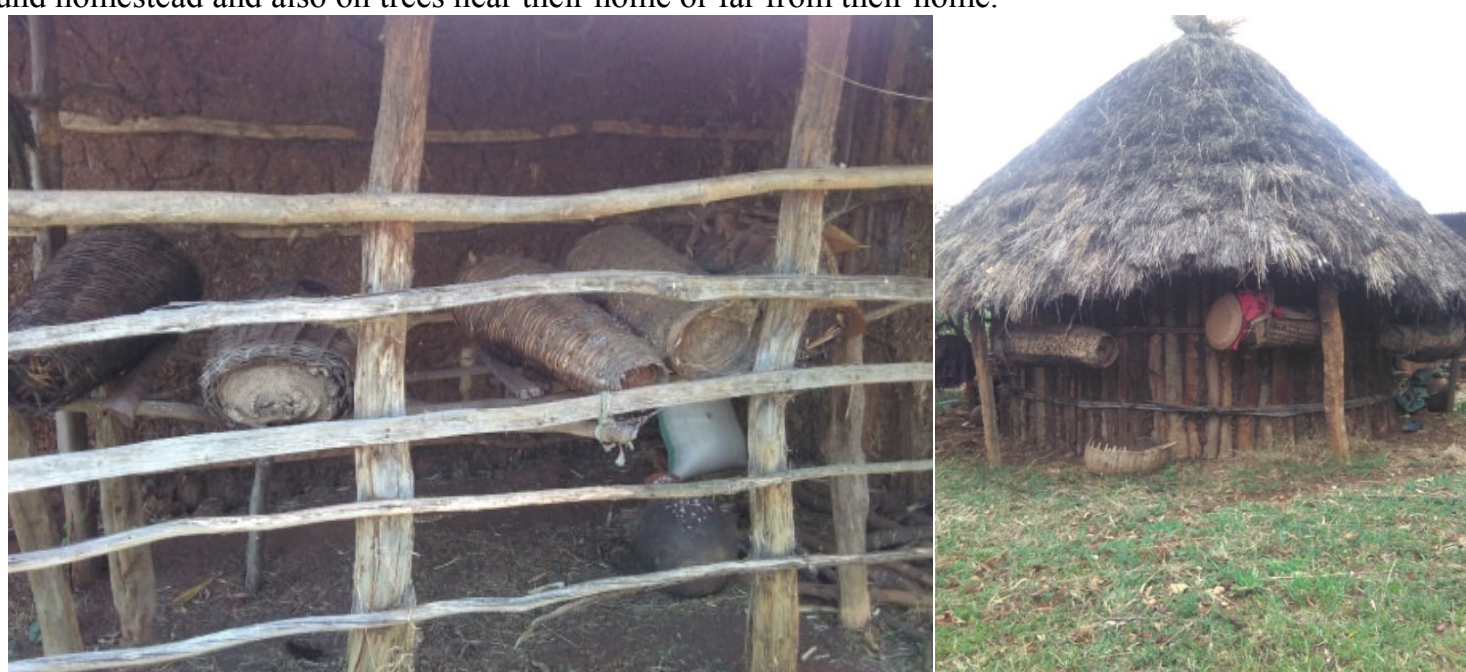

Plate 1: Traditional beehives on wood bed under thatched roof hut at home of a beekeeper (Photo: Yaregal 
Shiferaw in 2019)

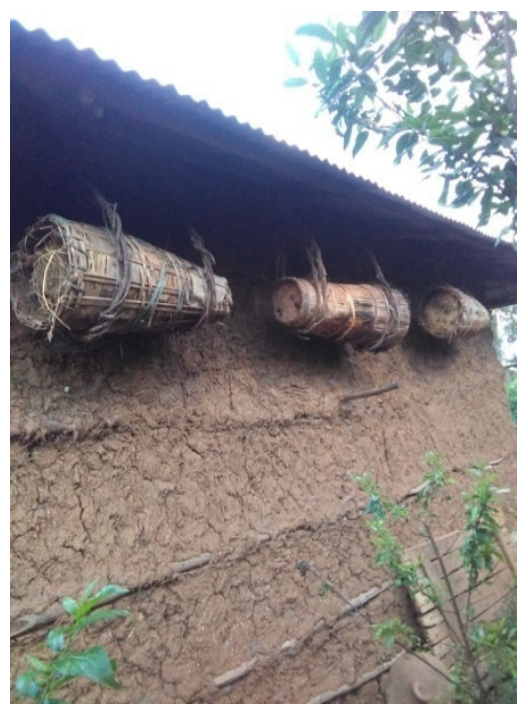

Plate 2: Traditional hive hanging under corrugated sheet at home of a beekeeper (Photo: by Yaregal Shiferaw in 2019)

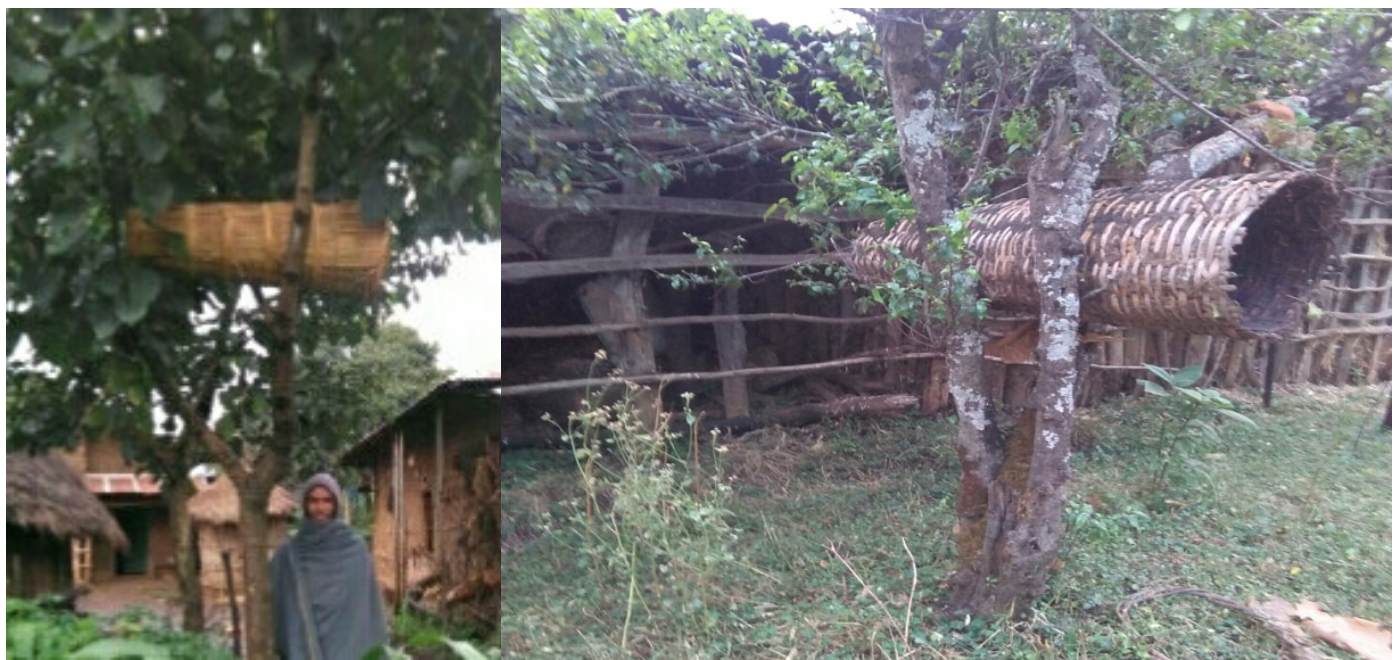

Plate 3: Tree apiary at homestead of beekeepers (Photo: Yaregal Shiferaw in 2019)

\subsubsection{Honeybee Colonies Owned By the Beekeepers}

As shown in Table 1, a nine month apiary inspection survey results showed that the overall number of honeybee colony positive hives owned by the beekeepers in Wehni Durbete Village was $52(81.3 \%)$ whereas the overall colony negative hives observed during the study period was 12 (18.7\%). From the sub-kebeles, the highest colony positive hives were observed in Tarenbora (26.9\%) followed by Adukita and Terefamba (19.2\%). Whereas, the highest colony negative hives were recorded in Adukita (33.3\%) followed by Mehalwehni (8.3\%).

Table 1: Number of honeybee colony positive and negative hives owned by the beekeepers

\begin{tabular}{lllll}
\hline Sub-Village & $\begin{array}{l}\text { Number } \\
\text { beekeepers }\end{array}$ & $\begin{array}{l}\text { Total Hives } \\
\text { N (\%) }\end{array}$ & $\begin{array}{l}\text { Total } \\
\text { Positive Hives } \\
\text { N (\%) }\end{array}$ & $\begin{array}{l}\text { Colony } \\
\text { Togal } \\
\text { Negative Hives } \\
\text { N (\%) }\end{array}$ \\
\hline Tarenbora & 10 & $16(25.0 \%)$ & $14(26.9 \%)$ & $2(16.7 \%)$ \\
Adukita & 10 & $14(21.8 \%)$ & $10(19.2 \%)$ & $4(33.3 \%)$ \\
Mehalwehni & 10 & $10(15.6 \%)$ & $9(17.3 \%)$ & $1(8.3 \%)$ \\
Terefamba & 10 & $12(18.8 \%)$ & $10(19.2 \%)$ & $2(16.7 \%)$ \\
Fendeka & 10 & $12(18.8 \%)$ & $9(17.3 \%)$ & $3(25.0 \%)$ \\
Overall & 50 & $64(100.0 \%)$ & $52(81.3 \%)$ & $12(18.7 \%)$ \\
\hline
\end{tabular}

\subsubsection{The Pattern of Honey Bee Colony Owning and Absconding}

The number of bee colony absconding hives rose in February (17.2\%) and peaked in April (23.43\%) with slight decline thereafter (Figure 2). Whereas the number of colony owning hives rose in October (7.8\%) and peaked in December $(96.8 \%)$ than the rest of the inspection months. 


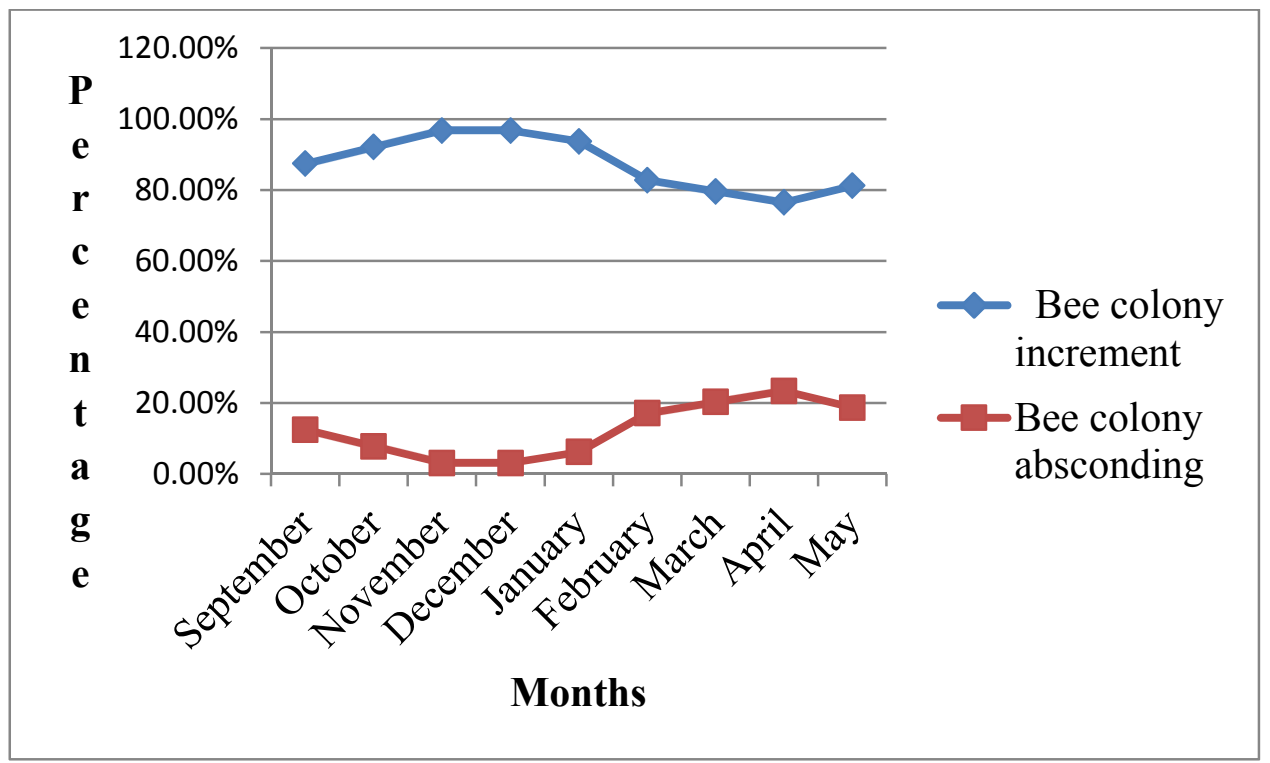

Figure 2: Patterns of honeybee colony owning and absconding from traditional hives in 2019

\subsubsection{Other Risk Factors Facing Beekeepers}

\subsubsection{Socio-demographic Profile of Respondents}

As shown in Table 2, all (100\%) of the beekeepers were males. The majority (56\%) of the beekeepers were in the age group between 41-50 years. The majority of the bee farmers $(58.0 \%)$ undergone elementary education followed by secondary education (26.0\%). The majority (54\%) of the beekeepers had between 2-4 years of beekeeping experience and a few (14.0\%) of them had less than two years of beekeeping experience.

Table 2: Demographic Characteristics of the Respondents $(\mathbf{N}=50)$

\begin{tabular}{llll}
\hline Parameters & Categories & Frequency & Percentage (\%) \\
\hline Gender & Male & 50 & $100 \%$ \\
Fge group & Female & & \\
& $18-20$ & 4 & 8.0 \\
& $21-40$ & 12 & 56.0 \\
Educational Status & $41-50$ & 6 & 24.0 \\
& Above 50 & 8 & 12.0 \\
Years of Beekeeping Experience & 29 & 16.0 \\
& Illiterate & 13 & 58.0 \\
& Primary & 7 & 26.0 \\
& Secondary and above & 14.0 \\
& $<2$ years & 27 & 54.0 \\
& 2-4years & 16 & 32.0 \\
\hline
\end{tabular}

\subsubsection{Risk Factors Enhancing Honeybee Colony Absconding by Season}

The respondents reported different challenges which affect the beekeeping activities in WDK such as pesticide and herbicide application that occurred in all seasons with the most occurrences in summer and spring (100\%) and the least occurrence in autumn (30\%) and winter (6\%) respectively (Table 3$)$. A significant association $(\mathrm{P}<0.05)$ existed between the challenges of bee colony absconding and season except for pests and predators.

Table 3: Reported causes of honeybee colony absconding by season in WDK in 2019

\begin{tabular}{|c|c|c|c|c|c|c|c|c|c|c|c|c|c|c|c|c|c|c|}
\hline \multirow{4}{*}{$\begin{array}{l}\text { Causes of } \\
\text { Colony } \\
\text { Absconding }\end{array}$} & \multicolumn{16}{|c|}{ Season of occurrence } & \multirow{4}{*}{$\begin{array}{l}\text { Chi- } \\
\text { square } \\
\left(\mathrm{X}^{2}\right)\end{array}$} & \multirow{4}{*}{$\begin{array}{l}P \text { - } \\
\text { value }\end{array}$} \\
\hline & \multicolumn{4}{|c|}{ Winter } & \multicolumn{4}{|c|}{ Summer } & \multicolumn{4}{|c|}{ Spring } & \multicolumn{4}{|c|}{ Autumn } & & \\
\hline & Yes & & No & & Yes & & No & & Yes & & No & & Yes & & No & & & \\
\hline & f & $\%$ & $\mathrm{f}$ & $\%$ & f & $\%$ & $\mathrm{f}$ & $\%$ & f & $\%$ & $\mathrm{f}$ & $\%$ & $\mathrm{f}$ & $\%$ & $\mathrm{f}$ & $\%$ & & \\
\hline Pesticides & 3 & 6 & 47 & 94 & 50 & 100 & 0 & 0 & 50 & 100 & 0 & 0 & 15 & 30 & 35 & 70 & 134.3 & 0.000 \\
\hline Lack of skill & 45 & 90 & 5 & 10 & 37 & 74 & 13 & 26 & 8 & 16 & 42 & 84 & 19 & 38 & 31 & 62 & 68.4 & 0.000 \\
\hline Deforestation & 46 & 92 & 4 & 8 & 15 & 30 & 35 & 70 & 19 & 38 & 31 & 62 & 50 & 100 & 0 & 0 & 64.5 & 0.000 \\
\hline Lack of forage & 43 & 86 & 7 & 14 & 24 & 48 & 26 & 52 & 0 & 0 & 50 & 100 & 38 & 76 & 12 & 24 & 89.2 & 0.000 \\
\hline $\begin{array}{l}\text { Pests, } \\
\text { predator }\end{array}$ & 41 & 82 & 9 & 18 & 39 & 78 & 11 & 22 & 37 & 74 & 13 & 26 & 36 & 72 & 14 & 28 & 1.641 & 0.650 \\
\hline Bee disease & 29 & 58 & 21 & 42 & 15 & 30 & 35 & 70 & 3 & 6 & 47 & 94 & 30 & 60 & 20 & 40 & 41.6 & 0.000 \\
\hline Drought & 22 & 44 & 28 & 56 & 0 & 0 & 50 & 100 & 4 & 8 & 46 & 92 & 26 & 52 & 24 & 48 & 51.9 & 0.000 \\
\hline
\end{tabular}

1.2.4. 3. Challenges Causing Honeybee Colony Absconding By Rank

As shown in (Fig 3) constraints were ranked based on its risk factors for beekeeping development such as pesticides 
supported by $(28 \%)$ of the respondents, lack of skills man power supported by $(20 \%)$ of the respondents, deforestation of trees supported by (18\%) of the respondents, lack of bee forage supported by $(12 \%)$ of the respondents, pests and predators supported by $(10 \%)$ of the respondents, drought (lack of rainfall) supported by $(6 \%)$ of the respondents, lack of water $(4 \%)$ of the respondents, diseases supported by $(2 \%)$ of the respondents. Pesticides and herbicide application were the top challenges whereas disease was the least one.

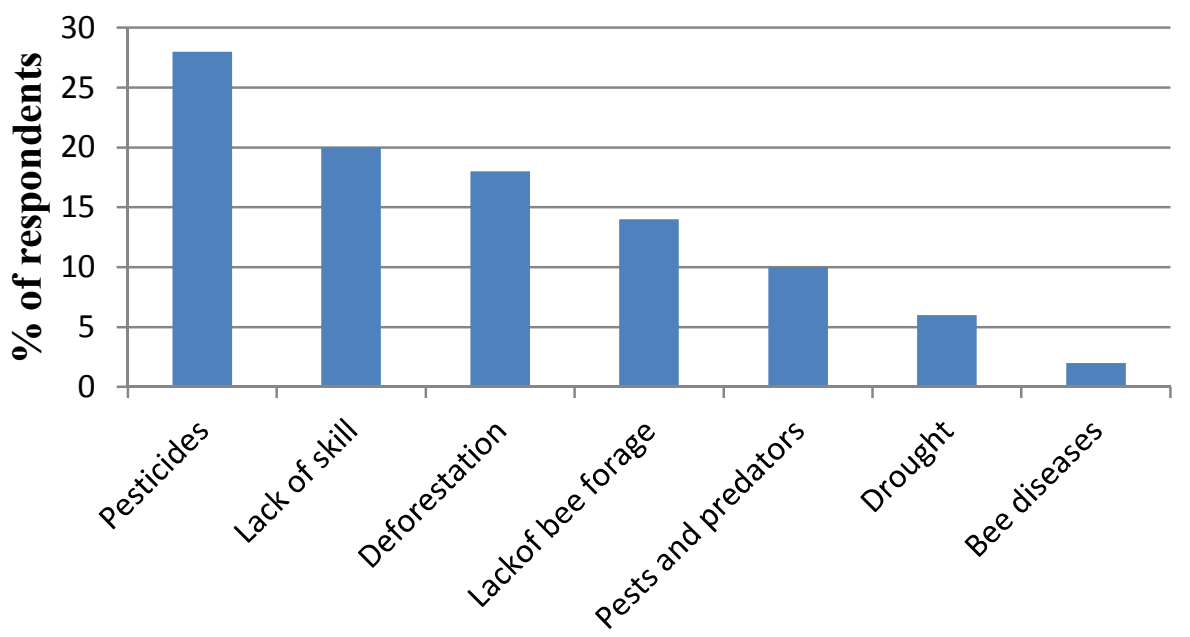

Factors causing Honey Bee Absconding

\subsection{Discussion}

\subsubsection{Traditional Apiaries Owned by the Beekeepers}

Results of apiary inspection survey showed that the majority of the beekeepers set their bee hives in backyard hanging under corrugated sheet and on beds in separate house constructed only for beekeeping and rarely set beehives on trees far away from their homestead. These observations agree with the works of (Kebede, 2011; Bihonegn, 2017) in Ethiopia. Keeping honeybee colonies under roof and on beds in separate houses in homestead were the common practice of beekeepers in the study setting. These traditional apiary practices of the beekeepers are safer and easily manageable as compared to tree apiaries which are labor intensive for climbing and subject to theft and honey pests.

\subsubsection{Honeybee Colonies Owned by the Beekeepers}

A nine month apiary inspection survey results showed that the overall number of honeybee colony positive hives owned by the beekeepers in Wehni Durbete Kebele was higher than the number of colony negative hives. These might be due to honey bee management practices of the beekeepers. The bee farmers keep their beehives in homestead and the honey bees were less exposed to theft and pests as explained earlier. Incidence of pests and predators, poor management, and lack of bee forage are the causes of colony absconding (Godifey, 2018). There were some variations among the sub-kebeles in the possession of honey bee colony positive and negative hives. Beekeepers in Tarenbora possessed the highest colony positive hives followed by those in Adukita and Terefamba. Whereas, beekeepers in Adukita owned the highest colony negative hives followed by those in Mehalwehni. This variation in honeybee colony possession among sub-kebeles could be due to beekeeping skill gap among the beekeepers and difference in apiary sites in relation of possession of bee forage. This agrees with the work of Addisu (2017) that reported similar observation from Dessie Zuria district in Ethiopia.

\subsubsection{Monthly Pattern of Honey Bee Colony Owning and Absconding}

Results showed that the number of bee colony absconding hives rose in February and peaked in April with slight decline thereafter. These would be expected because these months coincide with the dry months of the honey cropping season where there might be shortage of rain and bee flora. These results are supported by several studies) who reported that honeybee colony absconding increases from February to May due to shortage of rain and bee flora. The present results were also in line with Godifey (2018) who reported that incidence of pests and predators, poor management, shortage of rain and bee flora are the causes of colony absconding. According to BoA (2004) the peak dearth months of bee colony were during dry period from February to April due to lack of rain and bee forage and during rainy season from June to July because the pollen of flowering plants is diluted and the nectar is washed by rain. The results of this report also agrees with the works of Kebede and his colleagues (2013) who observed that in West Gojjam the months February, March and April were the peak months of shortage of forage and severity for bee colonies.

On the other hand, the number of colony owning hives rose in October and peaked in December than the rest of the honey cropping months. These findings coincide with a previous study from Ethiopia (Belie, 2009) who 
reported that most of the Ethiopian highlands are colored with golden-yellow bee flora from September to November and honey production increases because of abundance of local bee flora during this period. The work of Aynalem and Mekuriaw (2017) also assists the present results. The same source indicated that the main honey harvesting period in Amhara Region was October to November due to availability of moisture and peak flowering months of honey plants including pulse and oil crops. Kebede and Taddese (2014) also reported that September, October and November were the main months when colony swarming occurs because of availability of pollen in Ethiopia.

\subsubsection{Other Risk Factors Facing Beekeepers}

\subsubsection{Socio-demographic Profile of Respondents}

Results show that all of the beekeepers engaged in the traditional beekeeping practice were males. This is in line with the report of Kassa et al. (2015) who observed similar results from Jigjiga Zone, in Ethiopia. This shows that beekeeping activities were traditionally male dominated and may be considered as the only work of men in the study area and warrant further study. Beekeeping is a gender friendly activity particularly when it comes to the modern beekeeping and need special attention and action in the study setting. Results also revealed that the majority of the beekeepers were between age group 41-50 years. This survey was not in line with Tesfa (2013) who reported that the majority of the beekeepers were adolescent youths between age group 18-35 years. This implies that the beekeepers were matured youths than either immature youths or older aged adults further pointing the engagement of energetic and productive age group in beekeeping in the study area. With regard to educational status of the beekeepers the majority of them undergone elementary education a result similar to Belie (2009) who reported that majority of beekeepers had elementary education in Bure District of Amhara Region in Ethiopia. But it disagreed with the works of Shimelis (2017) in Ejere district, West Shewa Zone, Oromia Regional State in which most of the beekeepers were reported to be illiterate. When it comes to beekeeping experience, the majority of the beekeepers were reported to have between 2-4 years of beekeeping experience. This report disagrees with the findings of Tsegaye (2015) who observed that the experience of beekeepers in Waghimra and South Wollo Zone Amhara Region was more than five years.

\subsubsection{Risk Factors Associated with Honeybee Colony Absconding}

It was found that honeybee colony absconding was significantly associated with the application of agro-chemicals, lack of skills by the beekeepers, deforestation, shortage of bee forage, drought, and bee diseases. These findings agree with the works of (Belie, 2009; Tesfaye, 2015) who reported similar results from Bure Zuria District in Amhara and Bale Zone of Oromia Regional State respectively. Application of agro-chemicals particularly pesticides and herbicides were higher in summer and spring than winter and autumn. This might be expected because most agricultural activities take place during these seasons and local farmers use the chemicals to control weeds but winter and autumn are off seasons for rain fed agriculture in the study setting. Therefore, chemicals used for crop protection are the main pesticides that kill the honeybees and cause bee colony absconding and decline. Application of pesticides for crop protection accelerates colony decline (Ejigu et al. 2009; Tsegaye, 2015).

Deforestation and shortage of bee forage were also reported to be other major risk factors facing the traditional beekeepers. These would be due to over population and existence of basic needs such as fire wood, farmland, building house and charcoal production. This would be expected because "no trees no bees" and local forest resources are degraded and deteriorating due to over utilization and inefficient use of the resource which has negative impact on biodiversity of honeybees (Bedru et al 2006). Population pressure and lack of land use policy were key deriving forces for declining honeybee floras (Tessema, 2016) in Ethiopia. The shortage of bee forage mostly lack occurred from December to April which causes bee colony absconding. This is in line with the work of (Birhan et al. 2015) who reported that this period was dearth period for honey bee colonies.

Drought was also reported to be another problem that enhance honey bee colony absconding in the area. In line with this result (Ejigu, 2005; Kebede et al. 2008; Kebede and Taddese, 2014) reported that frequent occurrence of drought was a challenge to beekeeping development that usually occurs during January- April in Ethiopia.

Bee diseases were also reported to be another risk factor associated with bee colony absconding. The survey results showed that the diseases were reported to occur during winter and autumn especially from January to April during shortage of bee forage. This would be expected because the bees are vulnerable to various diseases, parasites and pests during dearth period (Begna 2006).

\subsubsection{Challenges Causing Honeybee Colony Absconding By Rank}

Pesticide and herbicide application were the top challenges facing beekeepers in the study area. This finding is in line with Kebede and Taddese (2014) who also reported similar results in Ethiopia. Another top problem of colony absconding in the study area was also inadequate skill of beekeepers. Bee colonies abscond from their hives because of lack of internal and external inspection survey of apiary sites or due to skill gap of beekeepers. These agree with the findings of (Kebede et al. 2008; Belie, 2009; Tsegaye 2015) who reported that lack of skill was a cause for colony decline and absconding. 


\subsection{Conclusions}

Results underscore that the local beekeepers own most bee colonies from October to December and loss most of them from January to April from their traditional hives. The top risk factors associated with bee colony absconding in the study setting were application of agro-chemicals, lack of skill by the beekeepers and deforestation respectively. Therefore it needs intervention to change traditional beekeeping practices through training and introducing improved beekeeping technologies that are suitable for local bee types and conditions.

\section{Competing interests}

The authors have read the manuscript and declared that no competing interests exist.

\section{Authors' contributions}

YN participated to the study design, conducted data collection, analysis and interpretation and drafted and revised the manuscript. OK involved in designing the study, revised the manuscript and has given approval of the version to be published. All authors read and approved the final manuscript.

\section{ACKNOWLEDGMENTS}

The authors of this manuscript are deeply grateful to Wehni Durbete kebele maize farmers for their hospitality and provision of necessary data for the study. The authors also acknowledge Wollega University Department of Biology for providing field facilities.

\section{Author details}

${ }^{1}$ Department of Biology, Wollega University, P. O. BOX 395, Nekemte, Ethiopia

\section{Reference}

Beyene T, David P (2007). Ensuring small-scale producers in Ethiopia to achieve sustainable and fair access to honey markets. Paper prepared for international development enterprises (IDE) and Ethiopian society for appropriate technology (ESAT), Addis Ababa, Ethiopia.

Kassaye A (2001). Promotion of beekeeping in rural sector of Ethiopia: Proceedings of the third National Annual Conference of Ethiopian Beekeepers Association (EBA), September 3-4, 2001, Addis Ababa, Ethiopia, pp.52-58.

Adgaba N (2002). Geographical races of the honeybees ( Apis mellifera) of the Northern region of Ethiopia. Ph.D dissertation Rhodes University, South Africa.

Ejigu K, Preston TR, Gebey T (2009). Constraints and prospects for apiculture research and development in Amhara region, Ethiopia.

Abebe B, Jatema D (2015). Survey on Major Honey Bee Pests and Predators in Oromia Special Zone Surrounding Finfine in Walmara District. European Journal of Biological Sciences 7: 62-70.

Belie T (2009). Honeybee Production and Marketing System in Bure District of Amhara Region, Ethiopia.MSc. Thesis, Bahir Dar University, Natural Science Faculty, Department of Animal Science and Technology, Bahir Dar.

Tesfaye B (2015). Beekeeping practices, Factors Affecting Production, Quality of Honey and Beeswax in Bale Zone, Oromia Region, Ethiopia, College of Agriculture and Environmental Sciences, School of Animal and Range Sciences, Master of Science in Agriculture, Haramaya University.

Bees for Development (2000).The role of beekeeping in rural development.B. and D, publ., 28pp. Commonwealth Secretariat. 2002. Uganda: Strategy for development of the apiculture sector Final report. EIDD, EMDD. London, $60 \mathrm{pp}$.

FAO (2009). Bees and their role in forest livelihoods, by Bradbear,N. Non-wood forest products No. 19, Rome.

Kebede A (2011). Honey Bee Production Practices and Honey Quality in Silti Wereda, Ethiopia. College of Agriculture and Environmental Sciences, School of Animal and Range Sciences, Msc. Thesis, Haramaya University.

Bihonegn A (2017).Assessment of Beeswax Production, Quality and Market Chains in Selected Districts of South Wollo Zone, Amhara Region, Ethiopia. MSc. Thesis, Bahir Dar University, College of Agriculture and Environmental Sciences Graduate Program,Bahir Dar.

Godifey G (2015).Epidemiology of Honey Bee Disease and Pests in Selected Zones of Tigray Region, Northern Ethiopia. MSc Thesis. Bahir Dar University. Bahir Dar, Ethiopia.124 pp.

BoA (Bureau of Agriculture), 2004. Amhara National Regional State, Beekeeping Manual. Bahir Dar, Ethiopia.

Kebede A, Tesfa A, Ejigu K (2013).Assessment of Current Beekeeping Management Practice and Honeybee Floras of Western Amhara, Ethiopia. International Journalof Agriculture and Biosciences, 2(5):196201.Retrieved from http://www.ijagbio.com/pdf- files/volume-2-no-5-2013/196-201.pdf.

Aynalem T, Mekuriaw Z (2017). Study on the Beekeeping Situation, the Level of Beekeepers Knowledge 
Concerning Local Honeybee Subspecies, Their Productive Characteristics, and Behavior in Eastern Amhara Region, Ethiopia., Msc. Thesis, Bahir Dar University, College of Agriculture and Environmental Science, Department of Animal Production and Technology, Bahir Dar, Ethiopia.

Kebede H, Taddese G (2014). Survey on honey production system, challenges and opportunities Hadya Zone, Ethiopia, Department of Animal Science, Wachemo University, Hossana, Ethiopia.

Kassa A, Gebresilassie G, Fikru S (2015).Assessment of Beekeeping Practices (Absconding, Bee Forage and Bee Diseases and Pests) in Jigjiga Zone, Somali Regional State of Ethiopia.Jigjiga University,College of Dry land Agriculture, Department of Animal and Range Science, Jigjiga, Ethiopia. Poult Fish Wildl Sci an open access journal Volume3: 135.doi:10.4172/2375-446X.1000135.

Tesfa A (2013). Assessment of Current Beekeeping Management Practice and Honey Bee Floras of Western Amhara,Ethiopia. Inter. J. Agri. Biosci. 2(5): 196-101.

Shimelis S (2017).Survey of Honey Production System and Honey Bee Disease and Pests in Ejere District West Shewa Zone,Oromia Regional State, Ethiopia. College of Veterinary Medicine and Agriculture, Department of Clinical studies MVSc program in Veterinary Epidemiology Addis Ababa University.

Tsegaye A (2015). Potential Threats to Honeybee Health with Emphasis on Varroamite in South Wollo and Waghimra Zones of Amhara Region, Ethiopia.MSc Thesis.Bahir Dar University, Bahir Dar, Ethiopia. 135pp.

Bedru B, Mathijs E, Muys B (2006): Economic valuation methods of forest rehabilitation in exclosures. Journal of the Drylands. 1(2): 165-170.

Tessema B (2016). Constraints and Opportunities of Honeybee Production and Honey Marketing Systems: A Case of Guji and Borena Zone of Oromia State. Department of Animal and Range Science, Bule Hora University, Ethiopia.

Birhan M, Sahlu S, Getiy Z (2015).Assessment of Challenges and Opportunities of Bee Keeping in and Around, Ethiopia.University of Gondar.Faculty of Veterinary Medicine, Department of Animal Production and Extension, Academic Journal of Entomology.8 (3): 127-131. P.O. Box: 196.

Begna D (2006). The occurrence of chalkbrood the (Ascosphaera APIs): A honeybee (Apis mellinfera L.). Diseases in West Shoa, Anim.Eth Prod. 6(1): 1-8. 